\title{
Hubungan Karakter Permukiman dengan Partisipasi Masyarakat dalam PengelolaAn SaMPah Rumah Tangga (STUdi KaSUS : SURODADI, KELURAHAN SISWODIPURAN DAN Perum Bumi Singkil Permai I Desa Karanggeneng, KeCAMATAN BOYOLALI)
}

\author{
Inarotu Duja, Kuswanto Nurhadi, Isti Andini \\ Program Studi Perencanaan Wilayah dan Kota, \\ Jurusan Arsitektur, Fakultas Teknik \\ Universitas Sebelas Maret, Surakarta \\ email: inarotuduja@gmail.com
}

\begin{abstract}
:
Every citizen who lived in settlements will definitely produce garbage, therefore the volume of waste continues to increase every time. While the final disposal is provided having a limited capacity, so that the waste management at the community level needs to be improved so that the amount of waste that goes to landfill can be reduced. Waste management at the community level is also done in Surodadi, Siswodipuran and Perum Bumi Singkil Permai (BSP) I, Karanggeneng, Boyolali. But to these two regions have different treatment in processing waste. The problem in this research is about how are the relations between the residential character and the community participation in waste management. The method used is the method of description that describes the relationship between the two factors through the depiction of the results of observations, questionnaires and interviews. The results of this study are the difference in terms of residential character, waste management system and participation from the community in garbage penelolaan in both regions. Economic conditions have relation with the community participation in the management of household waste. Livelihood, social and cultural interactions that evolve shown to has a relation with the community participation in the management of household waste. The level of income and education levels have no connection with participation from the community in waste management.
\end{abstract}

Keywords: Community Participation, Residentials, Waste Management,

\section{PENDAHULUAN}

Sampah dan permukiman merupakan dua hal yang tidak terpisahkan, karena setiap rumah tangga pasti memproduksi sampah setiap harinya. Cara konvensional yang digunakan untuk menangani menanani permasalahan sampah permukiman adalah dengan membuang sampah ke tempat sampah yan akhirnya dibuang ke TPA (Tempat Pembuangan Akhir)

Masalah lain akan timbul ketika kapasitas TPA yang terbatas sedangkan jumlah sampah terus bertambah seiring dengan bertambahnya jumlah penduduk dan pola konsumsi masyarakat. Solusinya adalah mengurangi jumlah sampah yang dibuang di TPA.
Salah satu cara yang dapat dilakukan yaitu dengan mengolah sampah di tingkat rumah tangga. Keberhasilan pengelolaan sampah rumah tangga tidak hanya ditentukan oleh kebijakan pemerintah saja, tetapi ditentukan juga oleh tingkat keterlibatan masyarakat dalam seluruh tahap kegiatan $(\mathrm{N}$. Saribanon dkk, 2007). Dengan memberikan porsi yang besar terhadap masyarakat dalam mengelola sampah diharapkan mampu meningkatkan kepekaan dan kepedulian terhadap lingkungan sekitar. Hal ini sesuai dengan teori yang menyebutkan bahwa salah satu dari lima atribut kota hijau adalah kepekaan dan kepedulian masyarakat (Program Pengembangan Kota Hijau (P2KH) Pedoman Pelaksanaan 2011). 
Seperti daerah lain, Kecamatan Boyolali juga memiliki permasalahan yang sama tentang sampah rumah tangga. Beberapa daerah di Kecamatan Boyolali mulai menerapkan pengelolaan sampah di tingkat rumah tangga untuk mengatasi permasalahan sampah rumah tangga. Dua wilayah yang telah menerapakan pengelolaan sampah rumah tangga adalah permukiman di Surodadi, Kelurahan Siswodipuran dan Perumahan Bumi Singkil Permai 1, Desa Karanggeneng, Kecamatan Boyolali.

Kedua wilayah tersebut memiliki karakter permukiman yang berbeda dan cara pengelolaan sampah yang berbeda pula. Tujuan dari penelitian ini adalah mengkaji hubungan karakter permukiman dengan partisipasi masyarakat dalam pengelolaan sampah rumah tangga di Kecamatan Boyolali.

\section{METODE}

\subsection{Ruang Lingkup}

Wilayah penelitian dibatasi di lingkup wilayah Kecamatan Boyolali. Perumahan yang diambil sebagai wilayah kajian adalah lingkungan perumahan di Surodadi, Kelurahan Siswodipuran dan Perumahan Bumi Singkil Permai 1, Desa Karanggeneng, Kecamatan Boyolali. Batasan aspek yang dibahas pada penelitian ini dibagi menjadi 3 kelompok yaitu kelompok karakter permukiman, sistem pengelolaan sampah dan karakter partisipasi masyarakat dalam pengelolaan sampah.

\subsection{Metode Analisis}

Penelitian ini menggunakan jenis penelitian kualitatif di mana data yang ada akan diolah secara deskriptif.

Menurut Nazir (2005) menyatakan bahwa metode penelitian deskriptif adalah metode penelitian dalam meneliti sebuah objek yang bertujuan untuk membuat deskripsi secara sistematis, faktual dan akurat mengenai faktafakta, sifat-sifat serta hubungan antara fenomena yang diselidiki. adalah:

Adapun tahapan analisis yang dilakukan

1. Analisis Identifikasi Karakter Permukiman.

2. Analisis Identifikasi Sistem Pengelolaan Sampah.
3. Analisis Identifikasi Partisipasi Masyarakat dalam Pengelolaan Sampah.

4. Analisis Hubungan Karakter Permukiman dengan Partisipasi Masyarakat dalam Pengelolaan Sampah.

\section{HASIL DAN PEMBAHASAN}

\subsection{Analisis Identifikasi Karakter Permukiman}

Dalam melakukan analisis identifikasi karakter permukiman dilakukan dengan metode deskripsi dari hasil observasi lapangan dan studi dokumen. Menurut Dyah (2010), karakter permukiman secara umum dapat dibagi menjadi tiga kelompok besar, yaitu:

1. Fisik Binaan.

Kelompok ini berkaitan dengan kenampakan fisik perumahan.

Terdapat perbedaan antara permukiman di Surodadi dan Perum BSP 1 dari segi fisik binaan. Perumahan formal (Perum BSP 1, Desa Karangganeng) lebih memiliki keteraturan dalam penataan wilayah dibandingkan dengan perumahan swadaya (Surodadi, Kelurahan Siswodipuran) yang tumbuh secara mandiri.

2. Kondisi Ekonomi.

Penduduk Surodadi lebih didominasi oleh warga yang telah menjadi pensiunan, sedangkan di Perum BSP 1, didominasi oleh warga yang memiliki mata pencaharian sebagai PNS. Dari segi pendapatan, kedua wilayah rata-rata penduduknya memiliki pendapatan lebih dari Rp 1.116.000,00 yang merupakan UMR Boyolali.

3. Kondisi Sosial

Rata-rata tingkat pendididkan penduduk di kedua wilayah sama-sama tinggi karena jumlah penduduk yang telah lulus peruruan tinggi sama-sama tinggi.

Dari hasil observasi yang telah dilakukan, di Surodadi lebih banyak pertemuan yang diadakan, mulai dari unit perkumpulan terkecil yaitu pertemuan Dasa Wisma yang ikuti oleh ibu-ibu. Berbeda dengan Perum BSP 1 di mana pertemuan yang dilakukan warga lebih sedikit karena banyak warga di Perum BSP 1 yang masih aktif bekerja sehingga intensitas pertemuan warga pun agak jarang dilakukan. Dapat dikatakan bahwa perumahan di Surodadi memiliki interaksi sosial lebih baik dari pada perum 
BSP 1, sehingga budaya yang berkembang masih dapat dilestarikan seperti kegiatan kerjabakti dan gotong royong yang masih kerap dilakukan untuk menjaga kebersihan kawasan.

\subsection{Analisis Identifikasi Sistem Pengelolaan Sampah}

Berdasarkan observasi dan wawancara yang telah dilakukan maka diperoleh sistem pengelolaan sampah pada masing-masing wilayah sebagai berikut:

1. Proses Pengelolaan sampah.

Pada permukiman di wilayah Surodadi, Kelurahan Siswodipuran proses pengolahan menggunakan sistem bank sampah dan pengomposan. Sedangkan di Perum BSP 1, Desa Karanggeneng proses pengolahan menggunakan sistem pemilahan sampah organik dan anorganik.

2. Aktor Pengelolaan Sampah.

Masyarakat dilibatkan secara penuh dalam pengelolaan sampah di Surodadi, Kelurahan Siswodipuran, tidak menutup kesempatan pula bagi pihak lain untuk ikut terlibat dalam mengelola bank sampah, seperti BLH dan pengepul sampah. Berbeda dengan yang dilakukan di Perum BSP 1, Desa Karanggeneng yang lebih banyak mengandalkan pihak luar yaitu petugas kebersihan untuk mengangkut sampah dari rumah tangga ke TPS

3. Jumlah timbulan sampah.

Jumlah timbulan sampah dari permukiman di wilayah Surodadi, Kelurahan Siswodipuran yang dibuang ke TPA berkurang setelah dilakukan pengelolaan sampah. Di Perum BSP 1, Desa Karanggeneng, jumlah timbulan sampah yang dibuang di TPA memiliki jumlah yang tidak jauh berbeda dari sebelum adanya pengelolaan sampah rumah tangga

Sistem pengelolaan sampah di Surodadi lebih teratur dan mendapat respon positif dari masyarakat, sedangkan di Perum BSP 1, pengelolaan sampah yang dilakukan lebih sederha yaitu hanya dengan melakukan pemilahan sampah organik dan anorganik. Hal ini dikarenakan kegiatan pengelolaan sampah di BSP 1 berasal dari pemerintah sehingga masyarakat tidak merasa memiliki kegiatan pengelolaan sampah rumah tangga.

\subsection{Analisis Identifikasi Partisipasi Masyarakat dalam Pengelolaan Sampah}

Dalam analisis identifikasi partisipasi masyarakat terlebih dahulu dilakukan menterjemahkan hasil wawancara yang diperoleh ke dalam indikator partisipasi masyarakat dalam pengelolaan sampah yang telah di susun sebelumnya (Lampiran 1, Tabel 1.). Kemudian dihitung rata-rata masingmasing wilayah.

$$
\begin{gathered}
\text { Rata }- \text { rata }=\frac{\text { Total Skor }}{\text { Jumlah Item }} \\
\text { Surodadi }=\frac{14}{5}=2,80 \\
\text { Perum BSP I }=\frac{8}{5}=1,60
\end{gathered}
$$

Partisispasi masyarakat Surodadi tergolong dalam kategori Degree of Citizen Power. Dalam derajat ini masyarakat dinilai telah mampu dan memiliki kewenangan dalam menentukan pengelolaan sampah rumah tangga di wilayahnya. Hal ini dibuktikan dengan segala sesuatu dalam pengelolaan sampah, baik itu berupa inisiatif, sistem pengelolaan, aturan, dan sumberdaya yang digunakan dalam pengelolaan sampah ditentukan oleh masyarakat.

Partisipasi masyarakat Perum BSP 1 dalam mengelola sampah tergolong dalam kategori non-participation. Hal ini diperkuat dengan sedikitnya porsi keterlibatan masyarakat dalam mengelola sampah.

\subsection{Analisis Hubungan Karakter Permukiman dengan Partisipasi Masyarakat dalam Pengelolaan Sampah}

Pada analisis untuk mengetahui hubungan antara karakter permukiman dengan partisipasi masyarakat dalam penelolaan sampah dibuat matriks yang mengkaitkan antara karakter permukiman dengan partisipasi masyarakat dalam pengelolaan sampah.

\subsubsection{Hubungan Kondisi Ekonomi dengan Partisipasi Masyarakat dalam Pengelolaan Sampah}

Tabel hubungan kondisi ekonomi dengan partisipasi masyarakat dalam pengelolaan sampah dapat dilihat di Lampiran 1 pada Tabel 2. Dari tabel tersebut diketahui bahwa: 
1. Kawasan dengan dominasi orang yang memiliki mata pencaharian yang lebih fleksibel (dari segi waktu) memungkinkan warganya untuk berkreasi dan memunculkan ide dalam memanfaatkan waktu dan tenaga mereka. Walaupun kedua wilayah sama-sama memiliki pendapatan rata-rata di atas UMR, namun inisiatif untuk mengelola sampah berbeda.

2. Daerah dengan dominasi warga yang bermata pencaharian yang lebih fleksibel waktu kerjanya memungkinkan warganya untuk berkumpul dan menyepakati aturan dalam pengelolaan sampah. Meski ratarata pendapatan penduduk di kedua wilayah sama-sama tinggi, tetapi dalam proses penyepakatan aturan memiliki perbedaan, sehingga tinggi rendahnya pendapatan tidak berpengaruh dalam penyepakatan aturan.

3. Perbedaan mata pencaharian dan pendapatan tidak mempengaruhi dari mana asal sumberdaya didapat. Hal ini dikarenakan untuk memaksimalkan usaha pengelolaan sampah rumah tangga tidak bisa hanya mengandalkan sumberdaya dari masyarakat itu sendiri, namun juga perlu mencari sumberdaya-sumberdaya lain yang berasal dari luar untuk membantu suksesnya pengelolaan sampah rumah tangga di wilayah tersebut.

4. Daerah dengan mayoritas warga pensiunan akan memiliki waktu yang lebih banyak untuk terlibat aktif dalam proses pengelolaan sampah rumah tangga. Pada kedua wilayah yang sama-sama memiliki rata-rata pendapatan yang tinggi, tetapi keterlibatan masyarakat dalam proses pengelolaan sampah berbeda.

5. Daerah dengan warga yang pensiun, memberikan kesempatan bagi semua warga untuk berperan aktif sebagai aktor dalam pengelolaan sampah. Tingkat pendapatan warga yang rendah tidak menjamin keterlibatan warga dalam mengelola sampah rumah tangga baik.

\subsubsection{Hubungan Kondisi Sosial dengan Partisipasi Masyarakat dalam Pengelolaan Sampah}

Tabel hubungan kondisi ekonomi dengan partisipasi masyarakat dalam pengelolaan sampah dapat dilihat di Lampiran 2 pada Tabel 3. Dari tabel tersebut diketahui bahwa:

1. Kedua wilayah sama-sama memiliki tingkat pendidikan yang tinggi, tetapi berbeda dalam pengambilan inisiatif. Wilayah dengan interaksi yang baik akan memacu warganya untuk memunculkan ide mengenai pengelolaan sampah. Daerah dengan budaya gotong-royong yang berkembang maka memberikan kesempatan bagi warga untuk memunculkan ide mengenai pengelolaan sampah.

2. Kedua wilayah sama-sama memiliki tingkat pendidikan yang tinggi, tetapi berbeda dalam penyepakatan aturan. Interaksi antar tetangga mempengaruhi penyepakatan aturan dalam pengelolaan sampah. Wilayah dengan interaksi yang baik akan memacu warganya untuk membuat dan menyepakati peraturan mengenai pengelolaan sampah. Daerah dengan budaya gotong-royong yang berkembang maka memberikan kesempatan bagi warga untuk membuat peraturan tentang pengelolaan sampah.

3. Kedua wilayah sama-sama memiliki tingkat pendidikan yang tinggi, dan samasama menggunakan sumberdaya dari dalam dan dari luar. Kedua wilayah berbeda dalam interaksi warga, tetapi sama-sama memanfaatkan sumberdaya dari dalam dan dari pihak luar. Kedua wilayah memiliki perbedaan dalam budaya gotong-royong, tetapi sama-sama menggunakan sumberdaya dari dalam dan dari luar.

4. Kedua wilayah sama-sama memiliki tingkat pendidikan yang tinggi, tetapi berbeda dalam peran aktif masyarakat dalam pengelolaan sampah. Wilayah dengan interaksi yang baik akan memacu warganya untuk lebih aktif dan terlibat dalam pengelolaan sampah. Daerah dengan budaya gotong-royong yang berkembang maka memberikan kesempatan bagi warga untuk aktif berpartisipasi dalam setiap proses pengelolaan sampah.

5. Kedua wilayah sama-sama memiliki tingkat pendidikan yang tinggi, tetapi berbeda dalam keterlibatan masyarakat dalam keterlibatan masyarakat sebagai 
aktor pengelola. Wilayah dengan interaksi yang baik akan memacu semua warganya untuk terlibat aktif sebagai aktor pengelola. Daerah dengan budaya gotongroyong yang berkembang maka memberikan kesempatan bagi semua warga untuk aktif dan turut serta sebagai aktor pengelola.

\section{KESIMPULAN}

Dari penelitian yang dilakukan mengenai hubungan karakter permukiman dengan partisipasi masyarakat dalam pengelolaan sampah rumah tangga yang telah dilakukan, diperoleh beberapa kesimpulan yaitu sebagai berikut:

1. Perumahan swadaya dan perumahan formal memiliki beberapa perbedaan. Surodadi sebagai perumahan swadaya memiliki karakter fisik binaan yang tidak teratur. Kondisi ekonomi baik, serta memiliki kondisi sosial yang baik. Perumahan BSP 1 sebagai perumahan formal memiliki fisik binaan yang teratur karena telah direncanakan dan ditata. Kondisi ekonomi yang baik dan kondisi sosial yang kurang baik, terutama dalam hal interaksi bertetangga.

2. Sistem pengelolaan sampah di kedua daerah berbeda. Perumahan swadaya (Surodadi) memiliki sistem pengelolaan sampah yang teratur, sedangkan Perumahan formal (Perum BSP 1) memiliki sistem pengelolaan sampah yang sederhana, banyak bergantung pada bantuan pihak luar dan belum memiliki dampak yang nyata dalam mengurangi timbulan sampah di TPA.

3. Perumahan swadaya Surodadi memiliki partisipasi masyarakat yang tinggi (degree of citizen power). Perumahan formal Perum BSP 1 memiliki tingkat partisipasi yang rendah (nonparticipation) karena masyarakat hanya diberikan komunikasi satu arah dari pemerintah.

4. Hubungan antara karakter permukiman dengan partisipasi masyarakat dalam pengelolaan sampah dapat dijelaskan melalui beberapa poin berikut ini:

a. Kondisi ekonomi: mata pencaharian memiliki hubungan terhadap partisipasi masyarakat dalam pengelolaan sampah. Masyarakat yang memiliki waktu kerja yang tidak mengikat atau lebih leksibel memungkinkan untuk berpartisipasi dalam pengelolaan sampah lebih baik. Sedangkan tingkat pendapatan tidak memiliki hubungan dengan partisipasi masyarakat dalam pengelolaan sampah.

b. Kondisi sosial: tingkat pendidikan tidak memiliki hubungan dengan partisipasi masyarakat dalam pengelolan sampah. Tingkat pengetahuan yang tinggi tidak menjamin masyarakat memiliki partisipasi yang baik dalam pengelolaan sampah rumah tangga. Sedangkan interaksi sosial dan budaya memiliki hubungan partisipasi masyarakat dalam pengelolaan sampah. Interaksi yang baik dan budaya mengenai kebersihan lingkungan yang masih berkembang di masyarakat, memberikan dorongan bagi masyarakat untuk berpartisispasi dalam pengelolaan sampah rumah tangga.

\section{REFERENSI}

Direktorat Jendral Penataan Ruang, 2011. Program Pengembangan Kota Hijau (P2KH) Panduan Pelaksanaan 2011. Kementrian Pekerjaan Umum

N. Saribanon, E. Soetarto, S. Hadi Sutjahjo, E. Gumbira Sa'id, Sumardjo. 2007. Jurnal: Pendekatan Tipologi dalam Pengembangan Partisipasi Masyarakat (Studi Kasus : Pengelolaan Sampah Permukiman Berbasis Masyarakat Di Kotamadya Jakarta Timur). Jurnal Teknik Lingkungan.

Nazir, Mohammad. 2005. Metode Penelitian. Jakarta: Ghalia.

Dyah, Ratih Wahyu. 2010. Jurnal: Penataan Permukiman di Kawasan Segiempat Tunjungan Kota Surabaya. Jurnal Tata Kota dan Daerah 
LAMPIRAN 1

Tabel 1. Tabel Penilaian Partisispasi Masyarakat dalam Pengelolaan Sampah

\begin{tabular}{|c|c|c|c|c|}
\hline Variabel Partisipasi & $\begin{array}{l}\text { Permukiman Surodadi, } \\
\text { Kelurahan Siswodipuran }\end{array}$ & Skor & $\begin{array}{c}\text { Perumahan BSP 1, Desa } \\
\text { Karanggeneng }\end{array}$ & Skor \\
\hline Asal Inisiatif & Kesepakatan masyarakat & 3 & Program Pemerintah & 1 \\
\hline $\begin{array}{l}\text { Proses } \text { Penyepakatan } \\
\text { Aturan }\end{array}$ & $\begin{array}{l}\text { Aturan ditentukan dan } \\
\text { disepakati oleh masyarakat }\end{array}$ & 3 & $\begin{array}{l}\text { Aturan telah ditetapkan tanpa } \\
\text { ada kesepakatan dari } \\
\text { masyarakat }\end{array}$ & 1 \\
\hline Asal Sumber Daya & $\begin{array}{llr}\text { Sumberdaya } & \text { (tenaga, materi) } \\
\text { sebagian } & \text { berasal } & \text { dari } \\
\text { masyarakat } & & \end{array}$ & 2 & $\begin{array}{llr}\text { Sumberdaya } & \text { (tenaga, } & \text { materi) } \\
\text { sebagian } & \text { berasal } & \text { dari } \\
\text { masyarakat } & & \end{array}$ & 2 \\
\hline Proses Pengelolaan & $\begin{array}{l}\text { Masyarakat terlibat dalam } \\
\text { seluruh proses pengelolaan }\end{array}$ & 3 & $\begin{array}{l}\text { Masyarakat terlibat dalam } \\
\text { sebagian proses pengelolaan }\end{array}$ & 2 \\
\hline Aktor Pengelolaan & $\begin{array}{l}\text { Seluruh masyarakat } \\
\text { merupakan aktor pengelolaan }\end{array}$ & 3 & $\begin{array}{l}\text { Sebagian masyarakat } \\
\text { merupakan aktor pengelolaan }\end{array}$ & 2 \\
\hline Total Skor & & 14 & & 8 \\
\hline
\end{tabular}

Tabel 2.Tabel Hubungan Kondisi Ekonomi dengan Partisipasi Masyarakat dalam Pengelolaan Sampah

\begin{tabular}{|c|c|c|c|c|}
\hline \multirow{2}{*}{$\begin{array}{l}\text { Variabel } \\
\text { Partisipasi }\end{array}$} & \multicolumn{2}{|c|}{ Mata Pencaharian } & \multicolumn{2}{|c|}{ Pendapatan } \\
\hline & Surodadi & Perum BSP 1 & Surodadi & Perum BSP 1 \\
\hline Asal Inisiatif & $\begin{array}{l}\text { Didominasi oleh penduduk } \\
\text { yang memiliki jam bekerja } \\
\text { tidak mengikat (pensiunan } \\
\text { dan ibu rumah tangga), } \\
\text { memiliki inisiatif dalam } \\
\text { mengelola sampah }\end{array}$ & $\begin{array}{l}\text { Didominasi dengan } \\
\text { penduduk yang masih } \\
\text { aktif bekerja, tidak } \\
\text { memiliki inisiatif untuk } \\
\text { mengelola sampah } \\
\text { tetapi beri oleh } \\
\text { pemerintah }\end{array}$ & $\begin{array}{l}\text { Didominasi penduduk } \\
\text { dengan rata-rata } \\
\text { pendapatan diatas } \\
\text { UMR, memiliki } \\
\text { inisiatif dalam } \\
\text { mengelola sampah }\end{array}$ & $\begin{array}{l}\text { Didominasi } \\
\text { penduduk dengan } \\
\text { rata-rata pendapatan } \\
\text { diatas UMR, tidak } \\
\text { memiliki inisiatif } \\
\text { dalam mengelola } \\
\text { sampah }\end{array}$ \\
\hline $\begin{array}{l}\text { Proses } \\
\text { Penyepakatan } \\
\text { Aturan }\end{array}$ & $\begin{array}{l}\text { Didominasi oleh penduduk } \\
\text { yang memiliki jam bekerja } \\
\text { tidak mengikat (pensiunan } \\
\text { dan ibu rumah tangga), } \\
\text { membuat aturan dengan } \\
\text { keuntungan ekonomis }\end{array}$ & $\begin{array}{l}\text { Didominasi dengan } \\
\text { penduduk yang masih } \\
\text { aktif bekerja, tidak } \\
\text { memiliki kewenangan } \\
\text { dalam membuat aturan }\end{array}$ & $\begin{array}{l}\text { Didominasi penduduk } \\
\text { dengan rata-rata } \\
\text { pendapatan diatas } \\
\text { UMR, membuat aturan } \\
\text { yang member } \\
\text { keuntungan ekonomis }\end{array}$ & $\begin{array}{l}\text { Didominasi } \\
\text { penduduk dengan } \\
\text { rata-rata pendapatan } \\
\text { diatas UMR, tidak } \\
\text { memiliki } \\
\text { kewenangan dalam } \\
\text { membuat aturan } \\
\end{array}$ \\
\hline $\begin{array}{l}\text { Asal Sumber } \\
\text { daya } \\
\text { Pengelolaan }\end{array}$ & $\begin{array}{l}\text { Didominasi oleh penduduk } \\
\text { yang memiliki jam bekerja } \\
\text { tidak mengikat (pensiunan } \\
\text { dan ibu rumah tangga), } \\
\text { memanfaatkan sumberdaya } \\
\text { dari dalam dan dari pihak } \\
\text { luar }\end{array}$ & $\begin{array}{l}\text { Didominasi dengan } \\
\text { penduduk yang masih } \\
\text { aktif bekerja, } \\
\text { sumberdaya diperoleh } \\
\text { dari dalam dan dari } \\
\text { pihak luar }\end{array}$ & $\begin{array}{l}\text { Didominasi penduduk } \\
\text { dengan rata-rata } \\
\text { pendapatan diatas } \\
\text { UMR, menggunakan } \\
\text { sumberdaya } \\
\text { masyarakat dan } \\
\text { bantuan dari luar } \\
\end{array}$ & $\begin{array}{l}\text { Didominasi } \\
\text { penduduk dengan } \\
\text { rata-rata pendapatan } \\
\text { diatas UMR, } \\
\text { sumberdaya } \\
\text { diperoleh dari dalam } \\
\text { dan dari pihak luar } \\
\end{array}$ \\
\hline $\begin{array}{l}\text { Proses } \\
\text { Pengelolaan } \\
\text { Sampah }\end{array}$ & $\begin{array}{l}\text { Didominasi oleh penduduk } \\
\text { yang memiliki jam bekerja } \\
\text { tidak mengikat (pensiunan } \\
\text { dan ibu rumah tangga), } \\
\text { terlibat aktif dalam } \\
\text { pengelolaan sampah }\end{array}$ & $\begin{array}{l}\text { Didominasi dengan } \\
\text { penduduk yang masih } \\
\text { aktif bekerja, kurang } \\
\text { terlibat dalam } \\
\text { pengelolaan sampah }\end{array}$ & $\begin{array}{l}\text { Didominasi penduduk } \\
\text { dengan rata-rata } \\
\text { pendapatan diatas } \\
\text { UMR, terlibat aktif } \\
\text { dalam pengelolaan } \\
\text { sampah }\end{array}$ & $\begin{array}{l}\text { Didominasi } \\
\text { penduduk dengan } \\
\text { rata-rata pendapatan } \\
\text { diatas UMR, kurang } \\
\text { terlibat dalam } \\
\text { pengelolaan sampah }\end{array}$ \\
\hline $\begin{array}{l}\text { Aktor } \\
\text { Pengelolaan } \\
\text { Sampah }\end{array}$ & $\begin{array}{l}\text { Didominasi oleh penduduk } \\
\text { yang memiliki jam bekerja } \\
\text { tidak mengikat (pensiunan } \\
\text { dan ibu rumah tangga), } \\
\text { semua masyarakat terlibat }\end{array}$ & $\begin{array}{l}\text { Didominasi dengan } \\
\text { penduduk yang masih } \\
\text { aktif bekerja, hanya } \\
\text { sebagian warga yang } \\
\text { mau berpartisipasi }\end{array}$ & $\begin{array}{l}\text { Didominasi penduduk } \\
\text { dengan rata-rata } \\
\text { pendapatan diatas } \\
\text { UMR, melibatkan } \\
\text { semua masyarakat }\end{array}$ & $\begin{array}{l}\text { Didominasi } \\
\text { penduduk dengan } \\
\text { rata-rata pendapatan } \\
\text { diatas UMR, hanya } \\
\text { sebagian masyarakat } \\
\text { yang terlibat }\end{array}$ \\
\hline
\end{tabular}




\section{LAMPIRAN 2}

Tabel 3. Tabel Hubungan Kondisi Sosial dengan Partisipasi Masyarakat dalam Pengelolaan Sampah

\begin{tabular}{|c|c|c|c|c|c|c|}
\hline \multirow{2}{*}{$\begin{array}{l}\text { Variabel } \\
\text { Partisipasi }\end{array}$} & \multicolumn{2}{|c|}{ Kependudukan } & \multicolumn{2}{|c|}{ Interaksi dengan tetangga } & \multicolumn{2}{|c|}{ Budaya } \\
\hline & Surodadi & Perum BSP 1 & Surodadi & Perum BSP 1 & Surodadi & Perum BSP 1 \\
\hline 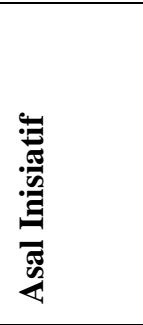 & $\begin{array}{l}\text { Tingkat } \\
\text { pengetahuan } \\
\text { yang tinggi, } \\
\text { memiliki } \\
\text { inisiatif dalam } \\
\text { mengelola } \\
\text { sampah }\end{array}$ & $\begin{array}{l}\text { Tingkat } \\
\text { pengetahuan } \\
\text { yang tinggi, } \\
\text { tidak memiliki } \\
\text { inisiatif dalam } \\
\text { mengelola } \\
\text { sampah }\end{array}$ & $\begin{array}{l}\text { Interaksi antar } \\
\text { tetangga yang } \\
\text { baik, memiliki } \\
\text { inisiatif dalam } \\
\text { mengelola } \\
\text { sampah }\end{array}$ & $\begin{array}{l}\text { Interaksi antar } \\
\text { tetangga yang } \\
\text { kurang baik, } \\
\text { tidak memiliki } \\
\text { inisiatif dalam } \\
\text { mengelola } \\
\text { sampah }\end{array}$ & $\begin{array}{l}\text { Budaya } \\
\text { gotong royong } \\
\text { berkembang, } \\
\text { memiliki } \\
\text { inisiatif dalam } \\
\text { mengelola } \\
\text { sampah }\end{array}$ & $\begin{array}{l}\text { Budaya } \\
\text { gotong royong } \\
\text { yang kurang } \\
\text { berkembang, } \\
\text { tidak memiliki } \\
\text { inisiatif untuk } \\
\text { mengelola } \\
\text { sampah }\end{array}$ \\
\hline 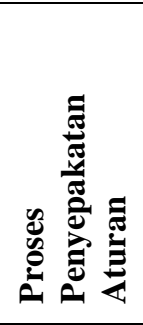 & $\begin{array}{l}\text { Tingkat } \\
\text { pengetahuan } \\
\text { yang tinggi, } \\
\text { memiliki } \\
\text { kesempatan } \\
\text { untuk membuat } \\
\text { peraturan }\end{array}$ & $\begin{array}{l}\text { Tingkat } \\
\text { pengetahuan } \\
\text { yang tinggi, } \\
\text { tidak memiliki } \\
\text { kewenangan } \\
\text { dalam membuat } \\
\text { aturan }\end{array}$ & $\begin{array}{l}\text { Interaksi antar } \\
\text { terangga yang } \\
\text { baik, memiliki } \\
\text { kesempatan } \\
\text { untuk } \\
\text { membuat } \\
\text { peraturan }\end{array}$ & $\begin{array}{l}\text { Interaksi antar } \\
\text { tetangga yang } \\
\text { kurang baik, } \\
\text { tidak memiliki } \\
\text { kewenangan } \\
\text { dalam membuat } \\
\text { aturan }\end{array}$ & $\begin{array}{l}\text { Budaya } \\
\text { gotong royong } \\
\text { berkembang, } \\
\text { membuat } \\
\text { aturan dengan } \\
\text { keuntungan } \\
\text { ekonomis }\end{array}$ & $\begin{array}{l}\text { Budaya } \\
\text { gotong royong } \\
\text { berkembang, } \\
\text { tidak memiliki } \\
\text { kewenangan } \\
\text { dalam } \\
\text { membuat } \\
\text { aturan }\end{array}$ \\
\hline 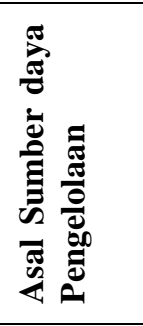 & $\begin{array}{l}\text { Tingkat } \\
\text { pengetahuan } \\
\text { yang tinggi, } \\
\text { menggunakan } \\
\text { sumberdaya } \\
\text { masyarakat dan } \\
\text { bantuan dari } \\
\text { luar }\end{array}$ & $\begin{array}{l}\text { Tingkat } \\
\text { pengetahuan } \\
\text { yang tinggi, } \\
\text { sumberdaya } \\
\text { diperoleh dari } \\
\text { dalam dan dari } \\
\text { pihak luar }\end{array}$ & $\begin{array}{l}\text { Interaksi antar } \\
\text { terangga yang } \\
\text { baik, } \\
\text { menggunakan } \\
\text { sumberdaya } \\
\text { masyarakat } \\
\text { dan bantuan } \\
\text { dari luar } \\
\end{array}$ & $\begin{array}{l}\text { Interaksi antar } \\
\text { tetangga yang } \\
\text { kurang baik, } \\
\text { sumberdaya } \\
\text { diperoleh dari } \\
\text { dalam dan dari } \\
\text { pihak luar }\end{array}$ & $\begin{array}{l}\text { Budaya } \\
\text { gotong royong } \\
\text { berkembang, } \\
\text { memanfaatkan } \\
\text { sumberdaya } \\
\text { dari dalam dan } \\
\text { dari pihak luar }\end{array}$ & $\begin{array}{l}\text { Budaya } \\
\text { gotong royong } \\
\text { berkembang, } \\
\text { sumberdaya } \\
\text { diperoleh dari } \\
\text { dalam dan dari } \\
\text { pihak luar }\end{array}$ \\
\hline 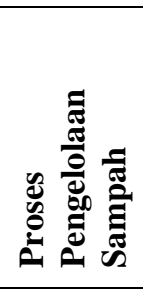 & $\begin{array}{l}\text { Tingkat } \\
\text { pengetahuan } \\
\text { yang tinggi, } \\
\text { terlibat aktif } \\
\text { dalam } \\
\text { pengelolaan } \\
\text { sampah }\end{array}$ & $\begin{array}{l}\text { Tingkat } \\
\text { pengetahuan } \\
\text { yang tinggi, } \\
\text { kurang terlibat } \\
\text { dalam } \\
\text { pengelolaan } \\
\text { sampah } \\
\end{array}$ & $\begin{array}{l}\text { Interaksi antar } \\
\text { terangga yang } \\
\text { baik, terlibat } \\
\text { aktif dalam } \\
\text { pengelolaan } \\
\text { sampah }\end{array}$ & $\begin{array}{l}\text { Interaksi antar } \\
\text { tetangga yang } \\
\text { kurang baik, } \\
\text { kurang terlibat } \\
\text { dalam } \\
\text { pengelolaan } \\
\text { sampah } \\
\end{array}$ & $\begin{array}{l}\text { Budaya } \\
\text { gotong royong } \\
\text { berkembang, } \\
\text { terlibat aktif } \\
\text { dalam } \\
\text { pengelolaan } \\
\text { sampah }\end{array}$ & $\begin{array}{l}\text { Budaya } \\
\text { gotong royong } \\
\text { berkembang, } \\
\text { kurang terlibat } \\
\text { dalam } \\
\text { pengelolaan } \\
\text { sampah } \\
\end{array}$ \\
\hline 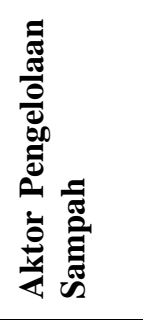 & $\begin{array}{l}\text { Tingkat } \\
\text { pengetahuan } \\
\text { yang tinggi, } \\
\text { melibatkan } \\
\text { semua } \\
\text { masyarakat }\end{array}$ & $\begin{array}{l}\text { Tingkat } \\
\text { pengetahuan } \\
\text { yang tinggi, } \\
\text { hanya sebagian } \\
\text { masyarakat } \\
\text { yang terlibat }\end{array}$ & $\begin{array}{l}\text { Interaksi antar } \\
\text { terangga yang } \\
\text { baik, } \\
\text { melibatkan } \\
\text { semua } \\
\text { masyarakat }\end{array}$ & $\begin{array}{l}\text { Interaksi antar } \\
\text { tetangga yang } \\
\text { kurang baik, } \\
\text { hanya sebagian } \\
\text { masyarakat } \\
\text { yang terlibat }\end{array}$ & $\begin{array}{l}\text { Budaya } \\
\text { gotong royong } \\
\text { berkembang, } \\
\text { semua } \\
\text { masyarakat } \\
\text { terlibat }\end{array}$ & $\begin{array}{l}\text { Budaya } \\
\text { gotong royong } \\
\text { berkembang, } \\
\text { hanya } \\
\text { sebagian } \\
\text { warga yang } \\
\text { mau } \\
\text { berpartisipasi }\end{array}$ \\
\hline
\end{tabular}

